\title{
RP-HPLC-DAD method for determination of olmesartan medoxomil in bulk and tablets exposed to forced conditions
}

RITESH N. SHARMA

SHYAM S. PANCHOLI

\author{
S. K. Patel College of Pharmaceutical \\ Education and Research, Ganpat \\ University, Kherva-382711 \\ Gujarat, India
}

\begin{abstract}
A simple, sensitive and precise RP-HPLC-DAD method was developed and validated for the determination of olmesartan medoxomil (AT-II receptor blocker) in the presence of its degradation products. Olmesartan medoxomil and all the degradation products were resolved on a $\mathrm{C}_{18}$ column with the mobile phase composed of methanol, acetonitrile and water $(60: 15: 25, V / V / V, \mathrm{pH} 3.5$ by orthophosphoric acid) at $260 \mathrm{~nm}$ using a photodiode array detector. The method was linear over the concentration range of $1-18 \mu \mathrm{g} \mathrm{mL}^{-1}$ and precise with $\mathrm{RSD}<1 \%$ in intra- and inter-day study. Excellent recoveries of 99.3 \pm 0.9 to $100.8 \pm 1.2 \%$ proved the accuracy of the method. Developed method was specific, as indicated by chromatographic resolution $>2.0$ for each peak and sensitive with LOD $0.03 \mu \mathrm{g} \mathrm{mL}^{-1}$ and $L O Q 0.1 \mu \mathrm{g} \mathrm{mL}^{-1}$. The method was used to study the drug degradation behavior under forced conditions. Four degradation products (DP-I, II, III, IV) were formed during the degradation study in $0.1 \mathrm{~mol} \mathrm{~L}^{-1}$ $\mathrm{HCl}$ whereas only DP-I, II and III were formed in water, $0.01 \mathrm{~mol} \mathrm{~L}^{-1} \mathrm{NaOH}$ and $3 \% \mathrm{H}_{2} \mathrm{O}_{2}$. No significant thermal or photolytic degradation was observed in solid drug. The method was applied successfully for the assay of olmesartan medoxomil in the tablet dosage form.
\end{abstract}

Keywords: olmesartan medoxomil, forced degradation, high performance liquid chromatography, stability

Stability can be defined as the capacity of a drug substance or drug product to sustain its identity, strength, quality, and purity throughout the retest or expiration period (1). Stability testing of an active substance or finished product provides evidence of the quality of a drug substance or drug product to remain acceptable up to the stated period under storage conditions stated on the label. The International Conference on Harmonization (ICH) guidelines Q1A (R2) require the use of a validated stability-indicating assay method (SIAM) for stability testing of a drug substance or product (2). It also empha-

\footnotetext{
*Correspondence; e-mail: riteshn.sharma@gmail.com
} 
sizes the conduct of a forced degradation study on the drug substance to generate information on degradation products that can form under the influence of hydrolytic, oxidative, thermal or photolytic degradation conditions.

Olmesartan medoxomil (OLM) (5-methyl-2-oxo-1,3-dioxolen-4-yl)methoxy-4- (1-hydroxy-1-methylethyl)-2-propyl-1-\{4-[2-(tetrazol-5-yl)-phenyl]phenyl\}methyl imidazo-5-carboxylate) (Fig. 1a) is a prodrug and rapidly hydrolyzes in plasma during absorption to form its active metabolite olmesartan (Fig. 1b) (3-5). It is a selective AT1 subtype angiotensin II receptor blocker $(6,7)$, which was recently approved by the US-FDA (8) to treat patients with hypertension. This reduces blood pressure by causing vasodilation and reducing peripheral resistance (9). OLM is also reported to be effective in animal models of atherosclerosis, liver disorders and diabetic nephropathy (10).

Methods of analyses of olmesartan medoxomil in biological fluids such as human plasma and urine by LC-MS and LC-MS-MS were reported previously (11-13). Use of capillary zone electrophoresis (CZE) for the determination of OLM in pharmaceutical dosage form has also been reported (14). No stability indicating assay of OLM in bulk and solid dosage form could be traced in the literature. However, the method that identified the main degradation products obtained during short-time storage using the hyphenated techniques has been reported (15). This method described the storage of tablets at $40{ }^{\circ} \mathrm{C} / 75 \% \mathrm{RH}$ for 6 months and identification of the degradation product by complementary use of the HPLC hyphenated techniques (LC-IR, LC-NMR and LC-MS) without isolation or purification processes.

In the present study, we aimed to develop and validate a stability indicating RP-HPLC-DAD assay method that allowed resolution, detection and quantitation of olmesartan medoxomil in the presence of degradation products obtained during the forced conditions in bulk substance and tablet dosage form.

a)

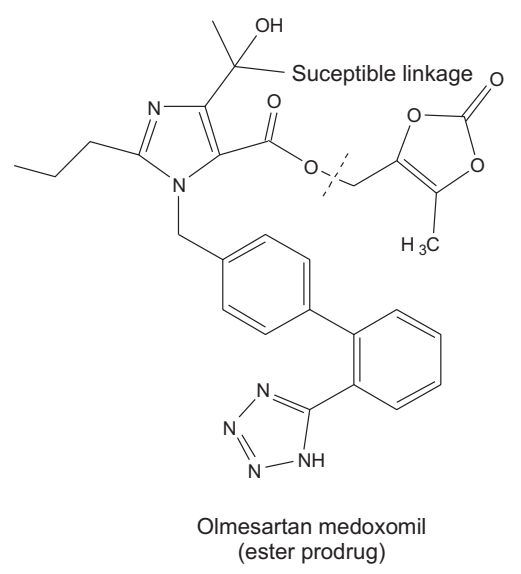

b)

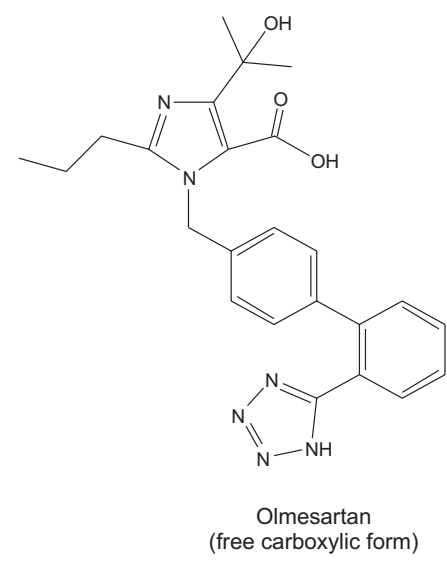

Fig. 1. Chemical structure of olmesartan medoxomil and its free carboxylic acid form olmesartan. 
R. N. Sharma and S. S. Pancholi: RP-HPLC-DAD method for determination of olmesartan medoxomil in bulk and tablets exposed to forced conditions, Acta Pharm. 60 (2010) 13-24.

\section{EXPERIMENTAL}

\section{Chemicals and reagents}

Olmesartan medoxomil was kindly provided as a gift a sample by Torrent Pharmaceutical Ltd. (India) with $99.94 \%$ purity. Tablet dosage form of olmesartan medoxomil (Olmecip, Cipla Ltd. India, $20 \mathrm{mg}$ ) was purchased from a local pharmacy. HPLC grade methanol and acetonitrile were purchased from S.D. Fine Chemical, India. Hydrochloric acid, sodium hydroxide pellets, hydrogen peroxide solution, and orthophosphoric acid were also purchased from S.D. Fine Chemical and were of analytical grade. Water for RP-HPLC was prepared by triple distillation in a glass still and filtered through a nylon $0.45 \mu \mathrm{m}$ membrane filter (Gelman Laboratory, India).

\section{Instruments}

The Shimadzu (Japan) LC system (LC-2010c HT) was equipped with a diode array detector (SPD-M20A), auto sampler (SIL-10ADvp) and column oven CTO-10A(C) vp. Chromatographic separations were performed using the Phenomenex (Torrance, USA) $\mathrm{C}_{18}$ column ( $250 \mathrm{~mm} \times 4.6 \mathrm{~mm}$ id, $5 \mu \mathrm{m}$ particle size) at $35^{\circ} \mathrm{C}$ column oven temperature and analyzed by LC solution software Shimad. For photolytic degradation, the UV cabinet producing short wavelength $(254 \mathrm{~nm})$ produced by Acemas Technocracy Prt. Ltd, India was used. High precision water bath and hot air oven (Narang Scientific Works, India) capable of controlling the temperature within \pm 1 and $\pm 2{ }^{\circ} \mathrm{C}$, respectively, were used for the hydrolytic and thermal degradation studies.

\section{Preparation of standard solutions}

A stock solution of olmesartan medoxomil was prepared by dissolving the drug in methanol to get a concentration of $1.0 \mathrm{mg} \mathrm{mL}^{-1}$. Fresh stock solution was prepared every day during the experiment. Working solution containing $100 \mu \mathrm{g} \mathrm{mL}^{-1}$ was prepared from this stock solution as well as seven calibration standards $\left(1-18 \mu \mathrm{g} \mathrm{mL}^{-1}\right)$ and quality control samples $\left(4,10\right.$ and $\left.14 \mu \mathrm{g} \mathrm{mL}^{-1}\right)$ by diluting appropriate aliquots of standard solutions.

\section{Preparation of sample solution}

Twenty tablets were weighed, transferred to a clean, dry mortar and well ground. Powder equivalent to $50 \mathrm{mg}$ drug was then transferred to a $100-\mathrm{mL}$ volumetric flask containing $50 \mathrm{~mL}$ methanol. The flask was attached to a rotary shaker for $10 \mathrm{~min}$ to disperse the material completely. The mixture was then sonicated for $20 \mathrm{~min}$ and centrifuged at 3,000 rpm for $5 \mathrm{~min}$. An aliquot of supernatant solution was diluted appropriately to give a solution of $500 \mu \mathrm{g} \mathrm{mL}-1$ and $10 \mathrm{~mL}$ of this solution was used for forced degradation studies. 
R. N. Sharma and S. S. Pancholi: RP-HPLC-DAD method for determination of olmesartan medoxomil in bulk and tablets exposed to forced conditions, Acta Pharm. 60 (2010) 13-24.

\section{Forced degradation studies}

Forced degradation of drug substances and drug products was carried out under acid/neutral/basic hydrolytic, oxidative, thermolytic, and photolytic stress conditions. For hydrolytic and oxidative degradation, drug solutions were prepared with a concentration of $500 \mu \mathrm{g} \mathrm{mL}^{-1}$. After degradation, aliquots were diluted with methanol to achieve a concentration of $10 \mu \mathrm{g} \mathrm{mL}^{-1}$. Methanol $(60 \%, V / V)$ was used for drug solubilization in acidic, neutral and oxidative media.

Hydrolytic degradation studies were carried out under acid $(0.1 \mathrm{~mol} \mathrm{~L}-1 \mathrm{HCl}, \mathrm{pH}$ 1.03), neutral (water, $\mathrm{pH} 7.12)$, and basic $\left(0.01 \mathrm{~mol} \mathrm{~L}^{-1} \mathrm{NaOH}, \mathrm{pH} 12.05\right)$ conditions at $60{ }^{\circ} \mathrm{C}$ as well as at room temperature over 12 to $48 \mathrm{~h}$. Oxidative degradation was carried out in a $3 \% \mathrm{H}_{2} \mathrm{O}_{2}$ solution at room temperature over $48 \mathrm{~h}$.

Thermal and photo degradation of drug substances and drug products was carried out in the solid state. For thermal degradation, the drug was spread in a borosilicate glass Petri dish and placed in the hot-air oven maintained at $60{ }^{\circ} \mathrm{C}$ for 10 days. Also, photolytic studies were carried out by exposing a thin layer of the solid drug in a Petri dish in the UV chamber for 10 days during which time the total light exposure equaled to $1.2 \times 10^{6} \mathrm{~lx} \mathrm{~h}$. After degradation, stock solutions were prepared by dissolving the samples in methanol to achieve a concentration of $1 \mathrm{mg} \mathrm{mL}^{-1}$. From these solutions, aliquots were diluted with methanol to get the final concentration of $10 \mu \mathrm{g} \mathrm{mL} \mathrm{L}^{-1}$ of OLM. Samples were withdrawn initially, subsequently at prefixed time intervals and stored at $2-8{ }^{\circ} \mathrm{C}$ until analysis for all forced conditions.

\section{Method development}

Detection wavelength for the HPLC study was selected as $260 \mathrm{~nm}$ after recording the UV spectrum from 190 to $400 \mathrm{~nm}$ of the drug and representative sample from each forced condition. The maximum area and peak selectivity of OLM was observed at this wavelength. The chromatographic conditions were optimized for resolution of the peak of the drug and degradation products under each forced condition by varying the stationary phase, proportion of methanol/acetonitrile/water in the mobile phase and the flow rate using representative samples from each forced condition. Several trials using various proportions of methanol and water as mobile phase were carried out. However, to attain the selective resolution of OLM and its degradation products, acetonitrile was introduced as the third solvent; apparent $\mathrm{pH} 3.5$ was adjusted by orthophosphoric acid. Subsequently, a mixture of different stress conditions was used to optimize the chromatographic conditions for resolving OLM and all the degradation products in a single run. An appropriate blank was injected before the analysis of all forced samples. Such an optimized method was then used to study the forced degradation behavior of OLM and was also applied in the stability indicating assay of OLM tablets.

\section{Validation of the method}

The optimized method was validated in accordance with the ICH guidelines (16). Linearity was determined by analyzing, in triplicate, standard drug solutions of concentrations $1,2,4,6,10,14$ and $18 \mu \mathrm{g} \mathrm{mL}-1$ using $20 \mu \mathrm{L}$ of the injection volume. For intra- 
R. N. Sharma and S. S. Pancholi: RP-HPLC-DAD method for determination of olmesartan medoxomil in bulk and tablets exposed to forced conditions, Acta Pharm. 60 (2010) 13-24.

-day precision, three quality control drug concentrations $\left(4,10\right.$ and $\left.14 \mu \mathrm{g} \mathrm{mL}^{-1}\right)$ were analyzed seven times on the same day whereas the same drug concentrations were analyzed on three different days for inter-day precision. Accuracy/recovery was evaluated by spiking the mixture of degradation samples with three known drug concentrations and calculating the percent recovery from the differences between the peak areas obtained for concentrated and diluted solutions. Signal-to-noise ratios were employed to estimate limits of detection (3:1) and limits of quantitation (10:1). The specificity of a method is its suitability for analysis of a substance in the presence of potential impurities. Specificity of the method was established through the study of the resolution (Rs) of OLM samples. Overall selectivity was established through determination of drug purity and Rs peak each time. Reproducibility of the method was established through separate studies on a mixture of degradation samples by different persons on the same chromatographic system as well as on different chromatographic systems in different laboratories on different days by another analyst. Various system suitability parameters were also evaluated on a mixture sample on six different days using freshly prepared mobile phase each time.

\section{RESULTS AND DISCUSSION}

\section{Method development and optimization}

The peak of pure OLM obtained using $50 \%$ methanol and $50 \%$ acetonitrile $(V / V)$ suggested to employ $70 \%$ methanol and $30 \%$ water $(V / V)$, pH 3.5 adjusted with orthophosphoric acid, as the mobile phase. Forced degradation samples were then analyzed using the same mobile phase flowing at a rate of $1.0 \mathrm{~mL} \mathrm{~min}^{-1}$ on a C18 column employing DAD detection. The method resolved the drug and degradation products under neutral, basic and oxidative conditions, but it could not resolve the cluster of peaks observed under acidic conditions. To separate the degradation products formed under acidic conditions, acetonitrile was introduced in the mobile phase and all other variables were kept the same. However, degradation products still remained unresolved under acidic conditions. The alteration in the stationary phase from $\mathrm{C} 18$ to $\mathrm{C} 8$ and the flow rate of the mobile phase did not furnish promising results either. Many compositions of different mobile phase strength were tried and, finally, mobile phase composed of methanol, acetonitrile and water $(60: 15: 25, V / V / V) \mathrm{pH} 3.5$ adjusted with orthophosphoric acid, at a flow rate of $1.0 \mathrm{~mL} \mathrm{~min}^{-1}$ on a C18 column, was used. This mobile phase could optimally resolve the OLM and all the degradation products formed under different conditions in the mixture sample in a single run (Fig. 2a). The relative retention time $\left(t_{R}\right)$ of each peak of the degradation product with respect to olmesartan medoxomil is given in Table I.

\section{Validation of the method}

Linearity. - Peak area and concentrations were subjected to the least square linear regression analysis to calculate the calibration equations and correlation coefficients. The calibration plot for OLM assay was linear over the calibration range 1-18 $\mu \mathrm{g} \mathrm{mL}^{-1}$, and the regression coefficient, slope and intercept were $0.998,541214 \pm 253.1$ and $340.9 \pm 6.2$, 
R. N. Sharma and S. S. Pancholi: RP-HPLC-DAD method for determination of olmesartan medoxomil in bulk and tablets exposed to forced conditions, Acta Pharm. 60 (2010) 13-24.

respectively. These results demonstrate an excellent correlation between the peak area and analyte concentration.
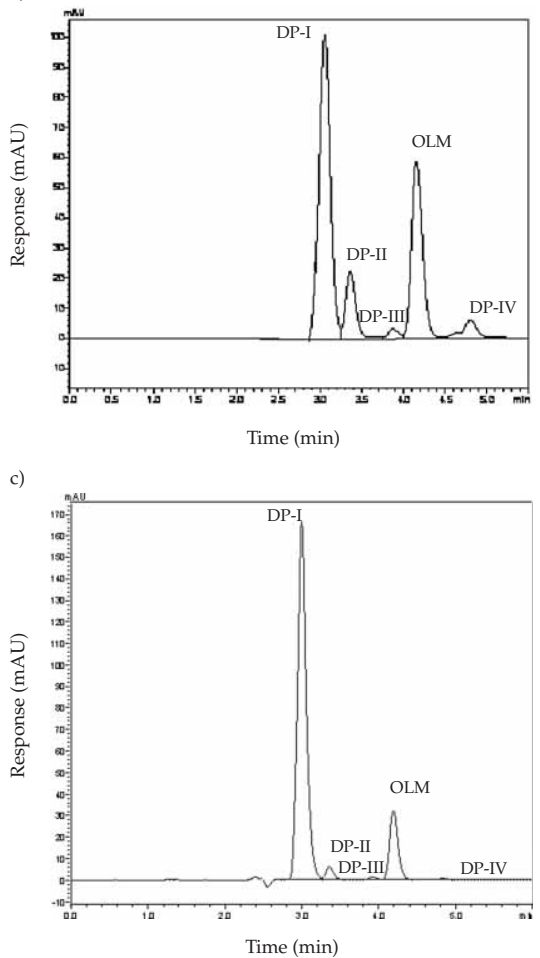

e)

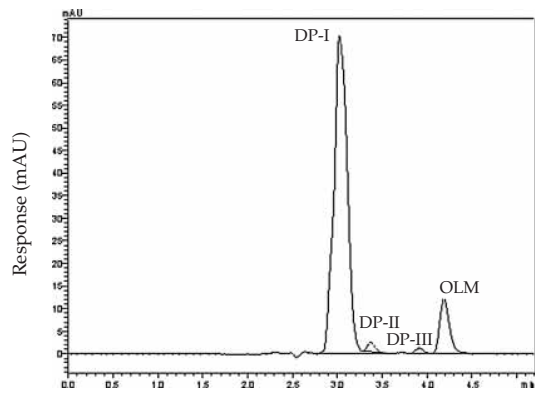

b)

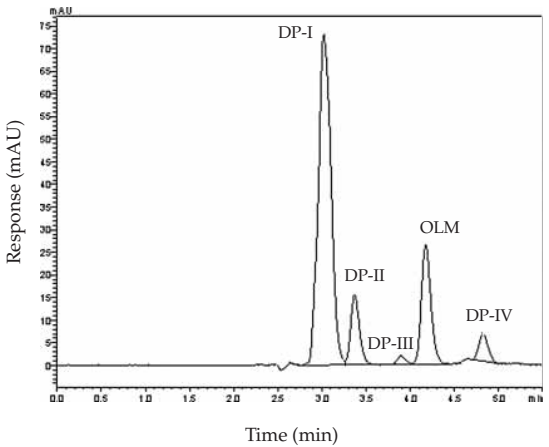

d)

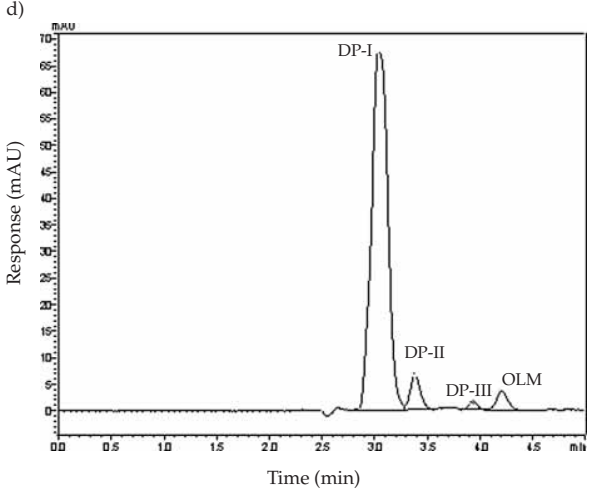

Time (min)

Fig. 2. HPLC chromatograms showing resolution of olmesartan medoxomil and degradation products in: a) mixture of forced degradation samples in a single run, b) $0.1 \mathrm{~mol} \mathrm{~L}^{-1} \mathrm{HCl}$ at $60{ }^{\circ} \mathrm{C}$ after 24 h, c) $0.01 \mathrm{~mol} \mathrm{~L}^{-1} \mathrm{NaOH}$ at RT after $4 \mathrm{~h}$, d) water at $60{ }^{\circ} \mathrm{C}$ after $48 \mathrm{~h}$, e) $3 \% \mathrm{H}_{2} \mathrm{O}_{2}$ at RT after $48 \mathrm{~h}$. 
R. N. Sharma and S. S. Pancholi: RP-HPLC-DAD method for determination of olmesartan medoxomil in bulk and tablets exposed to forced conditions, Acta Pharm. 60 (2010) 13-24.

Table I. Relative retention time, peak purity data and system suitability parameters of olmesartan medoxomil and its degradation products

\begin{tabular}{lccccc}
\hline \multirow{2}{*}{\multicolumn{1}{c}{ Parameter }} & \multicolumn{5}{c}{ Peak } \\
\cline { 2 - 6 } & DP-I & DP-II & DP-III & DP-IV & OLM \\
\hline Relative retention time $\left(t_{\mathrm{R}}\right)^{\mathrm{a}}$ & 0.740 & 0.809 & 0.932 & 1.154 & 1.000 \\
Peak purity index & 0.789 & 1.000 & 0.999 & 0.999 & 1.000 \\
Purity threshold & 0.842 & 0.998 & 0.883 & 0.974 & 0.999 \\
Asymmetry $(\mathrm{As})$ & 1.11 & 1.28 & 1.23 & 1.32 & 1.06 \\
Tailing factor $(\mathrm{T})$ & 1.044 & - & - & - & 1.058 \\
Chromatographic resolution $\left(R_{s}\right)$ & 1.91 & 1.24 & 1.99 & 2.05 & 1.16 \\
Capacity factor $\left(k^{\prime}\right)$ & 4.93 & 5.48 & 6.47 & 7.02 & 8.26 \\
Selectivity $(\alpha)^{\mathrm{b}}$ & 1.11 & 1.18 & 1.08 & 1.17 & \\
Number of theoretical plates $(N)$ & 2725.85 & 3164.63 & 3195.41 & 4215.38 & 2688.93 \\
\hline
\end{tabular}

a With respect to OLM.

$\mathrm{b}$ With respect to succeeding peak.

Limits of detection and quantification. - LOD was $0.03 \mu \mathrm{g} \mathrm{mL} \mathrm{m}^{-1}$ for OLM at a signal-to-noise ratio of 3:1 and the limit of quantification was determined as $0.1 \mu \mathrm{g} \mathrm{mL}^{-1}$ for OLM at a signal-to-noise ratio of 10:1.

Precision. - Intra-day precision was expressed throught relative standard deviation of seven repeated assays of samples at three concentration levels. Inter-day precision was determined by analyzing the same set of samples on five different days. RSD in the precision study for the OLM assay was less than $1.0 \%$ and confirmed that the method was highly precise. Results of the precision study for OLM by the proposed RP-HPLC-DAD method are given in Table II.

Recovery. - Standard addition method was used to examine the recovery of the RP-HPLC-DAD method (17). Recovery of OLM from bulk drug samples ranged from $99.3 \pm$ 0.9 to $100.7 \pm 1.0 \%$ and that from tablet dosage forms ranged from $99.5 \pm 0.8$ to $100.8 \pm$ $1.2 \%$ (Table III).

Table II. Precision data of the proposed RP-HPLC-DAD method

\begin{tabular}{ccc}
\hline $\begin{array}{c}\text { Actual conc. } \\
\left(\mu \mathrm{g} \mathrm{mL}^{-1}\right)\end{array}$ & \multicolumn{2}{c}{ Measured concentration $\left(\mu \mathrm{g} \mathrm{mL}^{-1}\right)^{\mathrm{a}}$} \\
\cline { 2 - 3 } & Interday & Intraday \\
10.0 & $4.0 \pm 0.1$ & $3.9 \pm 0.4$ \\
14.0 & $9.8 \pm 0.3$ & $10.2 \pm 0.5$ \\
\hline
\end{tabular}

\footnotetext{
a Mean $\pm \mathrm{SD}, n=7$.
} 
R. N. Sharma and S. S. Pancholi: RP-HPLC-DAD method for determination of olmesartan medoxomil in bulk and tablets exposed to forced conditions, Acta Pharm. 60 (2010) 13-24.

Table III. Recovery for bulk drug substance and drug product

\begin{tabular}{cccr}
\hline $\begin{array}{c}\text { Conc. of drug taken } \\
(\mu \mathrm{g} \mathrm{mL}-1)\end{array}$ & $\begin{array}{c}\text { Conc. of standard added } \\
\left(\mu \mathrm{g} \mathrm{mL}^{-1}\right)\end{array}$ & $\begin{array}{c}\text { Conc. found } \\
(\mu \mathrm{g} \mathrm{mL}-1)\end{array}$ & Recovery $(\%)$ \\
\hline Bulk drug substance & & & \\
10.0 & 5.0 & $14.9 \pm 0.2$ & $99.6 \pm 0.8$ \\
10.0 & 10.0 & $19.9 \pm 0.4$ & $99.3 \pm 0.9$ \\
10.0 & 15.0 & $25.1 \pm 0.3$ & $100.7 \pm 1.0$ \\
Drug product & & & \\
10.0 & 5.0 & $15.0 \pm 0.5$ & $100.8 \pm 1.2$ \\
10.0 & 10.0 & $20.0 \pm 0.3$ & $100.3 \pm 0.6$ \\
10.0 & 15.0 & $24.9 \pm 0.2$ & $99.5 \pm 0.8$ \\
\hline
\end{tabular}

Mean $\pm \mathrm{SD}, n=3$.

Specificity. - There was no interference due to placebo and sample diluents and degradation products. Resolution between closely eluting degradation products, i.e., between DP-I, DP-II, and between DP-III, OLM, were greater than 2.0, illustrated the chromatographic selectivity of the method.

Stability of stock solution. - During solution stability and mobile phase stability experiments, RSD for the OLM assay was within $1 \%$ for three replicates. Results of the solution stability and mobile phase stability experiments confirmed that standard solutions and solutions in the mobile phase were stable for up to $48 \mathrm{~h}$ during the OLM assay.

\section{Forced degradation}

During optimization of the hydrolytic degradation process, drug samples were initially placed in $0.1 \mathrm{~mol} \mathrm{~L}^{-1} \mathrm{HCl}, 0.1 \mathrm{~mol} \mathrm{~L}^{-1} \mathrm{NaOH}$ and in water at $60{ }^{\circ} \mathrm{C}$. However, after 24 and $48 \mathrm{~h}$, the OLM sample in $\mathrm{HCl}$ and water showed 31 and $12 \%$ degradation, respectively, while OLM in $0.1 \mathrm{~mol} \mathrm{~L}^{-1} \mathrm{NaOH}$ was completely degraded. Thus, we decided to carry out degradation at room temperature for the $0.1 \mathrm{~mol} \mathrm{~L}^{-1} \mathrm{NaOH}$ sample. The compound was completely degraded to DP-I instantly at room temperature. When $\mathrm{NaOH}$ concentration was lowered to $0.01 \mathrm{~mol} \mathrm{~L}^{-1}$, the sample containing OLM was $90 \%$ degraded at room temperature after $4 \mathrm{~h}$.

Degradation pattern under all forced conditions showed the presence of DP-I, which is the major degradation product of OLM formed during every degradation study. As illustrated in Fig. 2b for acidic hydrolysis all the degradation products (DP-I, II, III, IV) were observed in reasonable amounts. The OLM was degraded after $24 \mathrm{~h}$ at $60{ }^{\circ} \mathrm{C}$ in 0.1 mol L-1 $\mathrm{HCl}$; here there was more DP-II than in other stress condition samples. For hydrolysis in basic medium, $0.1 \mathrm{~mol} \mathrm{~L}^{-1} \mathrm{NaOH}$, almost all the drug had degraded at room temperature; however, $0.01 \mathrm{~mol} \mathrm{~L}^{-1} \mathrm{NaOH}$ at room temperature was appropriate for significant degradation. Three degradation products (DP-I, DP-II and DP-III) were present in these forced samples, DP-I being the major one (Fig. 2c). Degradation in neutral hyd- 
R. N. Sharma and S. S. Pancholi: RP-HPLC-DAD method for determination of olmesartan medoxomil in bulk and tablets exposed to forced conditions, Acta Pharm. 60 (2010) 13-24.
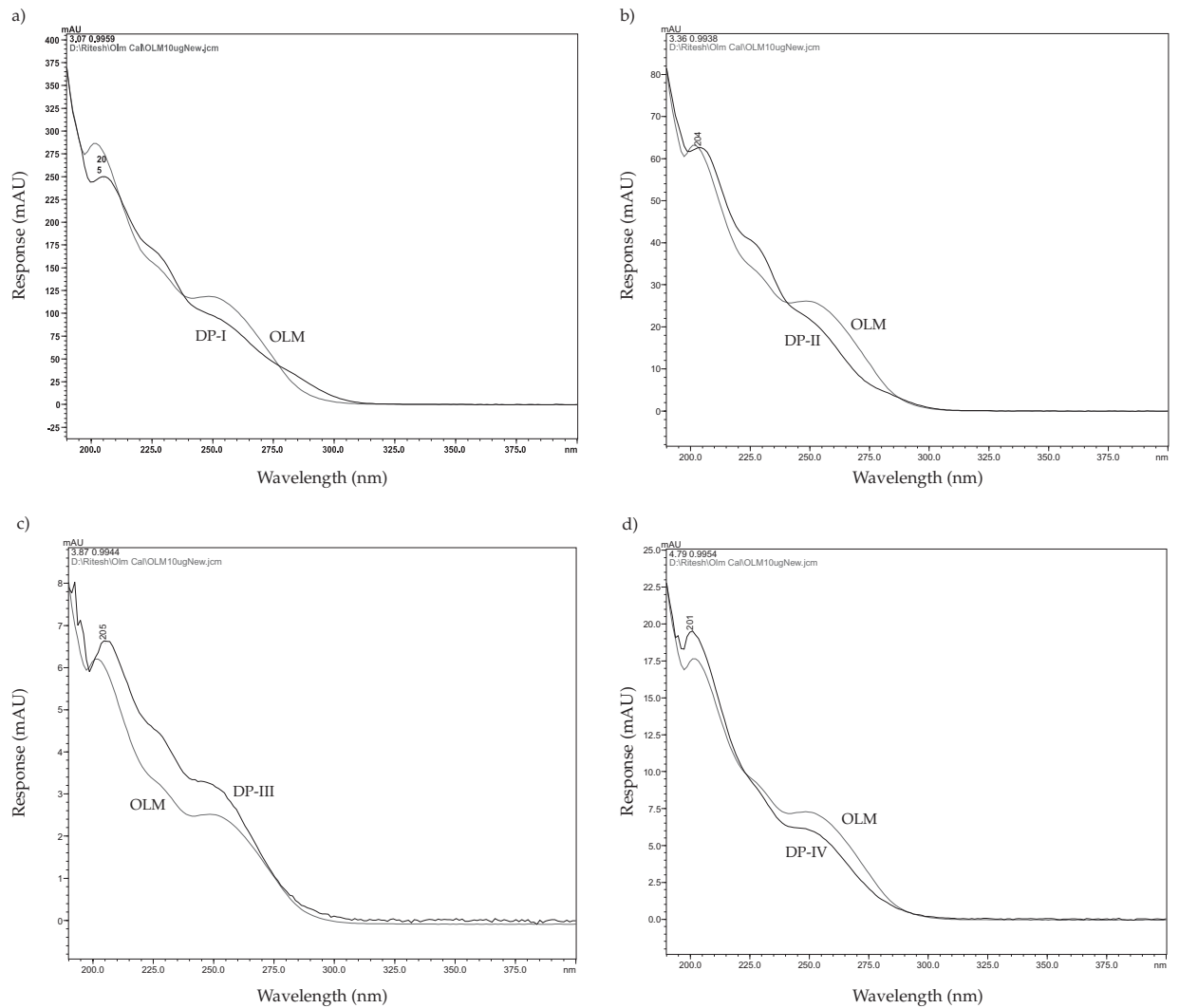

Fig. 3. UV spectra of olmesartan medoxomil (OLM) and degradation products: a) DP-I, b) DP-II, c) DP-III, d) DP-IV.

rolytic medium at $60{ }^{\circ} \mathrm{C}$ (Fig. 2d) occurred at a slower rate than under other hydrolytic conditions. Exposure to light and dark did not exhibit any significant difference in the degradation pattern under hydrolytic conditions. Results proved that the degradation of OLM was more pronounced under basic hydrolytic condition than under acidic and neutral conditions.

OLM degradation was $12 \%$ under oxidative conditions $\left(3 \% \mathrm{H}_{2} \mathrm{O}_{2}\right)$ at room temperature for $48 \mathrm{~h}$. Oxidative degradation produced DP-I, II and III, but DP-I and II were formed in minor amounts (Fig. 2e). No degradation was seen in solid drug kept at $60{ }^{\circ} \mathrm{C}$ for 10 days and no degradation was observed upon exposure to light intensity of $1.2 \times$ $10^{6} \mathrm{~lx}$ h either. Summary of the data for all forced degradations is given in Table IV.

Peak purity test suggested that the OLM peak as well as the peaks of OLM degradation products were pure for all the forced samples analyzed (Table I). No additional peak was observed after $5 \mathrm{~min}$ in chromatograms obtained for the extended runtime of $25 \mathrm{~min}$ in a sample study. 
R. N. Sharma and S. S. Pancholi: RP-HPLC-DAD method for determination of olmesartan medoxomil in bulk and tablets exposed to forced conditions, Acta Pharm. 60 (2010) 13-24.

Table IV. Summary of forced degradation study results

\begin{tabular}{lccc}
\hline \multicolumn{1}{c}{ Stress condition } & Time & OLM $(\%)$ & Remarks (major degradation product) \\
\hline $\begin{array}{l}\text { Acidic hydrolysis } \\
\left(0.1 \text { mol L } \mathrm{H}^{-1} \mathrm{HCl}, 60^{\circ} \mathrm{C}\right)\end{array}$ & $24 \mathrm{~h}$ & 68.7 & DP-I and II \\
$\begin{array}{l}\text { Basic hydrolysis } \\
\left(0.01 \text { mol L } \mathrm{L}^{-1} \mathrm{NaOH}, \mathrm{RT}\right)\end{array}$ & $4 \mathrm{~h}$ & 10.3 & DP-I \\
Aqueous hydrolysis $\left(60{ }^{\circ} \mathrm{C}\right)$ & $48 \mathrm{~h}$ & 88.1 & DP-I and II \\
Oxidation $\left(3 \% \mathrm{H}_{2} \mathrm{O}_{2}, \mathrm{RT}\right)$ & $48 \mathrm{~h}$ & 54.3 & DP-I \\
Thermal $\left(60{ }^{\circ} \mathrm{C}\right)$ & 10 days & 99.4 & No degradation product formed \\
Photo $(\mathrm{UV} 254 \mathrm{~nm})$ & 10 days & 99.8 & No major degradation product observed \\
\hline
\end{tabular}

OLM - olmesartan modoxomil; DP - degradation product

The UV spectrum of pure OLM was compared with the spectrum of the drug subjected to the different forced conditions; all the spectra showed slight changes in the absorption pattern. Purity of all degradation products was confirmed by comparing their spectra with the spectrum of OLM (Figs. 3a-d). Comparison of the spectra of two major degradation products, DP-I and II, with the OLM spectrum (Figs. 3a and b) suggested the absence of the ester moiety of OLM in both the DP-I and II, since the absorption maximum characteristic of the 5-methyl-2-oxo-1,3-dioxolen-4-yl-methyl group (ester moiety) in OLM at $260 \mathrm{~nm}$ was not visible. Olmesartan medoxomil is an ester prodrug and easily de-esterifies to its active metabolite olmesartan under hydrolytic conditions (4). Analogously to degradation products reported to be formed in losartan tablets stored at $40{ }^{\circ} \mathrm{C}$ and $75 \%$ relative humidity (18), the major degradation products are DP-I, likely to be the olmesartan free carboxylic acid form (Fig. 1b) and DP-II, the dimer of its free carboxylic acid form of olmesartan. The goal of determining OLM in the presence of degradation products by the proposed stability indicating RP-HPLC-DAD method was successfully achieved but the method can be also used for routine quality control of tablets.

\section{CONCLUSIONS}

The RP-HPLC-DAD method developed for quantitative analysis of olmesartan medoxomil in both bulk drug and pharmaceutical dosage forms is precise, accurate and specific. Satisfactory results were obtained by validation of the method. No attempt was made to quantify the degradation products; quantitation is possible after isolation of degradation products in pure form. This method can be used for the estimation of olmesartan medoxomil in the presence of degradation products obtained under different forced conditions.

Acknowledgements. - Author would like to thank Dr. B. G. Choudhary, Assistant Professor, S. K. Patel College of Pharmaceutical Education, Ganpat University, for his needfull suggestions during the research work. 
R. N. Sharma and S. S. Pancholi: RP-HPLC-DAD method for determination of olmesartan medoxomil in bulk and tablets exposed to forced conditions, Acta Pharm. 60 (2010) 13-24.

\section{REFERENCES}

1. FDA, Draft Guidance for Industry: Stability Testing of Drug Substances and Drug Products, FDA, Rockville 1998.

2. International Conference on Harmonisation of Technical Requirements for Registration of Pharmaceuticals for Human Use, ICH Harmonised Tripartite Guideline: Stability Testing of New Drug Substances and Products Q1A (R2), Step 5, ICH Geneva, Aug. 2003.

3. H. R. Brunner, The new oral angiotensin II antagonist olmesartan medoxomil: a concise overview, J. Hum. Hypertens. 16 (2002) S13-S16; DOI: 10.1038/sj/jhh/1001391.

4. H. Koike, T. Konse, T. Sada, T. Ikeda, S. Hyogo, D. Hinman, H. Saito, and H. Yanagisawa, Olmesartan medoxomil, a novel potent angiotensin II blocker, Ann. Rep. Snakyo Res. Lab. 55 (2003) 1-91.

5. D. E. Mire, T. N. Silfani and M. K. Pugsley, A review of the structural and functional features of olmesartan medoxomil, an angiotensin receptor blocker, J. Cardiovasc. Pharmacol. 46 (2005) 585-593; DOI: 10.1097/01.fjc.0000180902.78230.fd.

6. H. Koike, T. Sada and M. Mizuno, In vitro and in vivo pharmacology of olmesartan medoxomil, an angiotensin II type AT1 receptor antagonist, J. Hypertens. 19 (Suppl) (2001) S3-S14.

7. G. T. Warner and B. Jarvis, Olmesartan medoxomil, Drugs 62 (2002) 1345-1353.

8. O. Sagirli, A. Önal, S. E. Toker and D. Sensoy, Simultaneous HPLC analysis of olmesartan and hydrochlorothiazide in combined tablets and in vitro dissolution studies, Chromatographia 66 (2007) 213-218; DOI: 10.1365/s10337-007-0304-9.

9. K. Yoshihara, Y. Gao, H. Shiga, D. R. Wada and M. Hisaoka, Population pharmacokinetics of olmesartan following oral administration of its prodrug, olmesartan medoxomil: in healthy volunteers and hypertensive patients, Clin. Pharmacokin., 44 (2005) 1329-1342.

10. H. Nakamura, T. Inoue, N. Arakawa, Y. Shimizu, Y. Yoshigae, I. Fujimori, E. H. Nakamura, T. Inoue, N. Arakawa, Y. Shimizu, Y. Yoshigae, I. Fujimori, E. Shimakawa, T. Toyoshi and T. Yokoyama, Pharmacological and pharmacokinetic study of olmesartan medoxomil in animal diabetic retinopathy models, Eur. J. Pharmacol. 512 (2005) 239 -246; DOI: 10.1016/j.ejphar.2005.02.047.

11. V. V. Vaidya, S. M. Roy, S. M. Yetal, S. S. Joshi and S. A. Parekh, LC-MS-MS determination of olmesartan in human plasma, Chromatographia 67 (2008) 147-150; DOI: 10.1365/s10337-007-0453-x.

12. L. Dongyang, H. Pei, M. Nobuka, L. Xiaoming, L. Li and J. Ji, Quantitative determination of olmesartan in human plasma and urine by liquid chromatography coupled to tandem mass spectrometry, J. Chromatogr. B 856 (2007) 190-197; DOI: 10.1016/j.jchromb.2007.05.049.

13. N. J. Shah, B. N. Suhagia, R. R. Shah and N. M. Patel, Development and validation of a simultaneous HPTLC method for the estimation of olmesartan medoxomil and hydrochlorothiazide in tablet dosage form, Indian J. Pharm. Sci. 69 (2007) 834-836; DOI: 10.4103/0250-474X.39447.

14. C. Mustafa and A. Sacide, Development of a CZE method for the determination of olmesartan medoxomil in tablets, Chromatographia 66 (2007) 929-933; DOI: 10.1365/s10337-007-0424-2.

15. T. Murakami, H. Konno, N. Fukutsu, M. Onodera, T. Kawasaki and F. Kusu, Identification of a degradation product in stressed tablets of olmesartan medoxomil by the complementary use of HPLC hyphenated techniques, J. Pharm. Biomed. Anal. 47 (2008) 553-559; DOI: 10.1016/j.jpba. 2008.02.021.

16. International Conference on Harmonization of Technical Requirements for Registration of Pharmaceuticals for Human Use, ICH Harmonized Tripartite Guidelines, Validation of Analytical Procedure: Text and Methodology Q2 (R1), Current Step 4 version, ICH Geneva, Nov. 2005.

17. G. W. Ewing, Instrumental Methods of Chemical Analysis, 5th ed., Lippincott-Raven, Philadelphia 1995, pp. 484-486.

18. Z. Zhao, Q. Wang, E. W. Tsai, X. Z. Qin and D. Ip, Identification of losartan degradates in stressed tablets by LC-MS and LC-MS/MS, J. Pharm. Biomed. Anal. 20 (1999) 129-36; DOI: 10.1016/S0731-7085(99)00004-7. 
R. N. Sharma and S. S. Pancholi: RP-HPLC-DAD method for determination of olmesartan medoxomil in bulk and tablets exposed to forced conditions, Acta Pharm. 60 (2010) 13-24.

$S A \check{Z} E T A K$

\section{RP-HPLC-DAD metoda za određivanje olmesartan medoksomila kao čiste supstancije i u tabletama izloženih razgradnji}

RITESH N. SHARMA i SHYAM S. PANCHOLI

U ovom radu razvijena je i validirana jednostavna, osjetljiva i precizna RP-HPLC-DAD metoda za određivanje olmesartan medoksomila (inhibitor AT-II receptora) u prisutnosti njegovih razgradnih produkata. Olmesartan medoksomil i razgradni produkti kromatografirani su na $\mathrm{C}_{18}$ koloni uz mobilnu fazu metanol/ acetonitril/voda (60:15:25 $V / V / V ; \mathrm{pH} 3,5$ podešen ortofosfornom kiselinom) pri $260 \mathrm{~nm}$ uz detektor s fotodiodnim nizom. Metoda je linearna u koncentracijskom rasponu 1-18 $\mu \mathrm{g} \mathrm{mL}^{-1}$ i precizna s RSD < $1 \%$ tijekom ispitivanja repetabilnosti i intermedijarne ponovljivosti. Povrat od 99,3 $\pm 0,9$ do $100,8 \pm 1,2 \%$ dokazuje točnost metode. Razvijena metoda je specifična na što ukazuje kromatografsku rezoluciju veću od 2,0 i osjetljiva $\left(L O D=0,03 \mu \mathrm{g} \mathrm{mL}^{-1}\right.$ i $\left.L O Q=0,1 \mu \mathrm{g} \mathrm{mL} \mathrm{m}^{-1}\right)$. Metoda je upotrebljena za praćenje razgradnje olmesartan medoksomila u uvjetima potencirane razgradnje. $\mathrm{U} 0,1 \mathrm{~mol} \mathrm{~L}^{-1} \mathrm{HCl}$ detektirana su četiri razgradna produkta (DP-I, II, III, IV), a u vodi, $0,01 \mathrm{~mol} \mathrm{~L}^{-1} \mathrm{NaOH}$ i $3 \% \mathrm{H}_{2} \mathrm{O}_{2}$ samo DP-I, II i III. U čvrstom agregatnom stanju nije primjećena značajna termička ni fotolitička razgradnja ljekovite tvari. Metoda je uspješno primijenjena za određivanje olmesartan medoksomila u tabletama.

Keywords: olmesartan medoksomil, razgradnja, tekućinska kromatografija visoke učinkovitosti, stabilnost

S. K. Patel College of Pharmaceutical Education and Research, Ganpat University, Kherva-382711

Gujarat, India 